\title{
A NEW VERSION OF THE HOLOCENE STRATIGRAPHY IN ESTONIA
}

\author{
Anto RAUKAS, Leili SAARSE, and Siim VESKI
}

Eesti Teaduste Akadeemia Geoloogia Instituut (Institute of Geology, Estonian Academy of Sciences), Estonia pst. 7, EE-0001 Tallinn, Eesti (Estonia)

Received 20 October 1994, accepted 8 June 1995

\begin{abstract}
A new modified Holocene stratigraphical chart for the continental and marine deposits is presented. The chronozone boundaries are correlated with those of the Nordic countries and instead of pollen zones pollen assemblage zones are proposed. As the latter are time-transgressive, they are not strictly bound up with the chronozones. For the marine deposits it is suggested to use local units until the acceptance of the generally approved standard subdivision.
\end{abstract}

Key words: Holocene, Late-Glacial, stratigraphical chart, marine and continental deposits, unit and boundary stratotypes, pollen assemblage zones, physical dating methods.

\section{INTRODUCTION}

In 1993, the Baltic States, Estonia, Latvia, and Lithuania accepted new local stratigraphical schemes for all stratigraphical units and approved the regional charts. Three more or less independent local schemes of the Quaternary deposits comparable to the previous ones (Каяк et al., 1976) were accepted: a general one for the Quaternary and additional schemes for the Holocene and Late-Glacial deposits. These schemes have parallel subdivisions for continental and marine deposits. Biostratigraphical units are based on the pollen assemblage zones (PAZs). Radiocarbon dates served as the chronological tool.

According to the international rules, stratigraphical charts should be based on the unit and boundary stratotypes. Unfortunately, in Estonia and other Baltic States stratotype sections for the Holocene deposits have not been officially accepted yet. This work is still in progress.

\section{HISTORICAL BACKGROUND}

The first rather simple stratigraphical schemes of the Estonian Holocene deposits were published already in the last century. Applying pollen analysis, Thomson (1925) proposed his biostratigraphical scheme which he modified slightly after having studied several new localites (Thomson, 1930, 1933, 1939). His scheme was supplemented by chronology, climatic periods, the main constituents of forest, Baltic Sea stages, and archaeological periods. The next Holocene stratigraphical scheme, proposed by K. Orviku (Орвику, 1956) was based on different litho-, morpho-, and biostratigraphical evidences. The biostratigraphical data on 
Stratigraphy of the Late-Glacial and Holocene deposits in Estonia. Late-Glacial stratigraphy after R. Pirrus

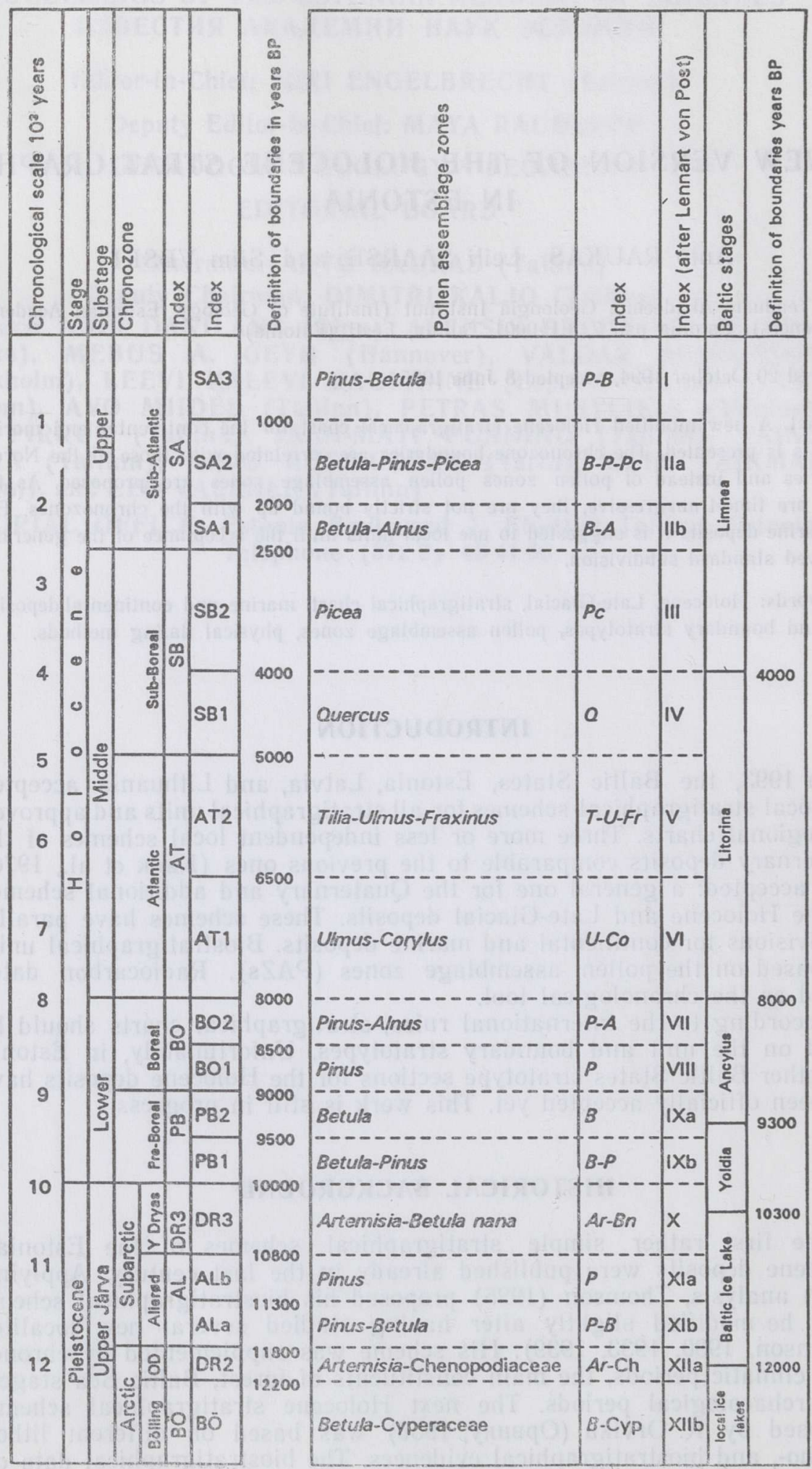


continental deposits were mostly generalized by L. Orviku (Ôpвику, 1960), and on marine sediments by Kessel (Кесceл, 1960). The Holocene stratigraphical scheme compiled by K. Orviku started from the Allerød and comprised thus the main part of the Late-Glacial named by him Old Holocene. In the 1960s he differentiated the Late-Glacial and Holocene stratigraphy. The result was a rather detailed scheme which comprised subdivisions for the continental and marine deposits, but lacked chronostratigraphy (Aaloe et al., 1960; Orviku, 1960). Later the marine part of the chart was more than once improved by Kessel (Кессел, 1961, 1966). The correlation of marine deposits and shorelines with the neighbouring countries was given by Kessel and Raukas (Кессел \& Раукас, 1981).

The application of physical dating methods since the end of the $1950 \mathrm{~s}$ (Ильвес et al., 1974) has made it feasible to add the chronostratigraphical scale and to connect it with the biozones. Yet, it was not until after more than ten years that the first official stratigraphical chart of the Estonian Holocene deposits was accepted. It was compiled under the leadership of K. Orviku and accepted in May 1976 (Kaяк et al., 1976). In principle, it was similar to the proposed new stratigraphical chart. The main differences concerned chronostratigraphy, the age of the chronozones, and instead of the pollen zones the PAZs were proposed. The new official stratigraphical chart (Table) was formally compiled by R. Pirrus, A. Raukas, and S. Veski based on the multiple studies of the continental and marine deposits. The chart was accepted at the session of the Estonian Stratigraphic Commission in May 1993 and a week later it was approved at the Stratigraphic Conference of the Baltic States in Vilnius. The regional chart for the Baltic States was approved at the same session of the conference. In both of these charts PAZs are strictly correlated with the chronozones but the former are time-transgressive even in such a small country as Estonia (Saarse et al., in press). In the present chart we did not mark the borders of the PAZs with a continuous line, but simply gave the succession of them.

The new stratigraphical chart is based on the data of H. Kessel, K. Kimmel, T. Koff, H. Mäemets, Reet Männil, L. Orviku, R. Pirrus, G. Rennel, A. Sarv, K. Veber, and S. Veski (biostratigraphy), E. Ilves, A. Liiva, J.-M. Punning, and R. Rajamäe (chronostratigraphy), T. Kiipli, J. Lutt, A. Raukas, R. Ramst, and L. Saarse (lithostratigraphy). Up to now 45 Holocene sequences have been studied using contemporaneously the bioand chronostratigraphical approaches. Unfortunately, only part of them correspond to the international standards.

\section{METHODS AND CONCEPTS}

An accurate and high-resolution chronology is extremely important in Holocene stratigraphy. In our studies several modern physical methods $\left({ }^{14} \mathrm{C}\right.$, TL, OSL, EPR) were used, but they all have their limitations and errors. The chronostratigraphical timescale presented in the Table is mainly based on the ${ }^{14} \mathrm{C}$ dates. Problems arise in connection with the radiocarbon dates, especially with those yielded by North-Estonian calcareous lacustrine sediments which due to hard water and reservoir effect give an "apparent" age.

As it has long been known, radiocarbon years deviate from the calendar years and have to be calibrated. In recent years the German oak dendrochronology has been extended to 7938 yr BC and pine chronology to 9439 yr BC (Kromer \& Becker, 1993). According to these calibrations, the Holocene/Pleistocene boundary is about 1110 years older than indicated by uncalibrated radiocarbon dates. The deviations of ${ }^{14} \mathrm{C}$ dates from 


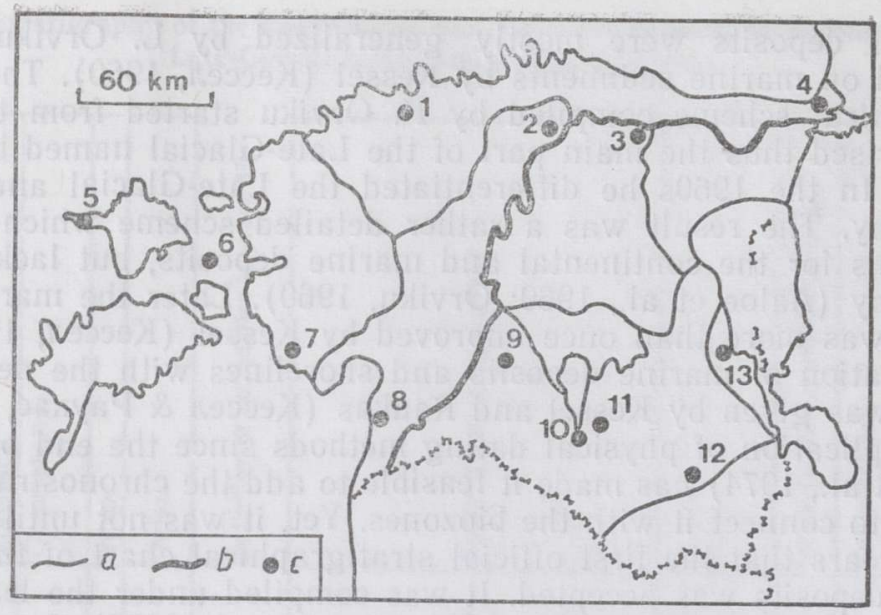

Biotic areas after Saarse \& Raukas (1984). a, boundary between the IGCP biotic areas; $b$, boundary between the West- and East-Baltic biotic areas; $c$, sites mentioned in the text: 1, Ulemiste; 2, Tара; 3, Kulina; 4, Sininõmmè; 5, Kõpu; 6, Väinameri; 7, Ermistu; 8, Rannametsa; 9, Loodi; 10, Väike-Emajõgi; 11, Rõngu; 12, Väimela Alajärv; 13, Saviku.

calendar years have a clear trend to increase with age. In different levels there are "plateaus", which hamper the usage of the calibrated dates. Therefore we have used uncalibrated ${ }^{14} \mathrm{C}$ data in the chronostratigraphical investigations in Estonia. The Estonian dendrochronological timescale is based on church and castle log tree ring countings and goes back to 960 yr AD (Aluve, 1978). Unfortunately, it is based only on a small number of measurements. The dendrochronological scale of living trees is short (Läänelaid, 1982).

Pollen zones are of particular importance in dividing and correlating deposits. They are based on the geographical migration of the terrestrial plants and might be repeated in sequences (Mangerud et al., 1974). There are several sequences in Estonia where it is impossible to differentiate between the upper and lower Picea zones, or where Pinus pollen is dominant already in the Pre-Boreal (Ulemiste, Ermistu). To overcome it the PAZs proposed by Donner (1971) have been defined. The pollen zones as well as PAZs are time-transgressive and their strict correlation with the chronozones over large areas could lead to serious mistakes. Therefore local stratigraphical charts for different palaeoecological regions are badly needed.

In the frame of the IGCP Project No. 158 "Palaeohydrology in the temperate zone during the last 15000 years", L. Saarse divided the territory of Estonia into two areas, West and East Estonia, taking into account the recommendations of the project leaders (Berglund, 1979), the subdivisions carried out in the neighbouring countries, Estonian landscapes (Varep, 1964), and natural regions (Paykac, 1978), geobotanical division (Laasimer, 1965), and limnological regions (Mäemets, 1976). The boundary of these is quite close to that of Lower and Upper Estonia by Tammekann (1933), consequently they correspond to the area below and above the Baltic Ice Lake maximum limit $B_{3}$. Within these two areas seven type regions have been distinguished (Saarse \& Raukas, 1984). This subdivision served as the basis for selecting the Holocene reference sites and areas for the Holocene stratigraphy in the continental part of Estonia (Fig.).

Since continental sequences are, as a rule, sensitive to lake-level fluctuations and climatic oscillations which are recorded in litho- and 
biofacies (Saarse \& Harrison, 1992), they provide additional material for the stratigraphical subdivision and correlations. This was taken into account in our most recent studies as well (Saarse et al., in press).

\section{THE HOLOCENE/PLEISTOCENE BOUNDARY}

In 1969, the INQUA Congress in Paris accepted the Pleistocene/Holocene boundary as $10000{ }^{14} \mathrm{C}$ yr BP and R. W. Fairbridge (oral. comm.) proposed the selection of the Holocene boundary stratotype at some suitable site that could be dated at around $10000 \pm 250$ radiocarbon years. The Pleistocene/Holocene transition is marked by great oscillations in magnetic declination and inclination, rapid melting of the ice cover, and the adjustment rates of the hydro- and glacio-isostasy. Recent investigations have demonstrated that the stratigraphical markers are asynchronous and the criteria used for determining the Holocene/Pleistocene boundary in one area may be unrecognizable in another region.

Lithological changes of sediment composition, the changes in microand macrofossil assemblages at the Younger Dryas/Pre-Boreal boundary in Estonia, however, fit well with the boundary proposed in Paris if to use uncalibrated ${ }^{14} \mathrm{C}$ dates. For example, the accumulation of organic sediments in SE Estonian lakes started about 10200 yr PB (in Saviku $10200 \pm 90$ yr ВР, ТА-328, Сарв \& Ильвес, 1975), changing the accumulation of sand, silt or clay, which had prevailed during the Late-Glacial.

\section{STRATIGRAPHY OF THE CONTINENTAL DEPOSITS}

There are 9836 peat bogs (Orru et al., 1992) and about 1150 lakes with an area of more than 1 ha in Estonia (Mäemets, 1977). The maximum thickness of peat $(16.8 \mathrm{~m})$ has been recorded in a small kettle hole at Vällamäe (Пуннинг et al., 1985). Usually, the peat layer is up to $5-6 \mathrm{~m}$ thick. The maximum thickness of organic lacustrine deposits is $18 \mathrm{~m}$ (Väimela-Alajärv), commonly $3-5 \mathrm{~m}$, lake marl 6-7 m (Tapa, Kulina), travertine 5-6 m (Loosi, Rõngu), alluvial deposits $15 \mathrm{~m}$ (Väike-Emajõgi) and aeolian deposits 15-20 m (Sininõmme, Kõpu, Rannametsa, Fig.). Lake and mire deposits have mostly been studied for stratigraphical purposes. For the zonation Nilsson's pollen zones were used.

The terms Pre-Boreal, Boreal, Atlantic, etc. were used in climato-, bio-, and chronostratigraphical studies which has caused several misunderstandings. For example, in several studies Pre-Boreal, Boreal, Atlantic, etc. have been differentiated having not a single radiocarbon date. In 1974, Mangerud et al. recommended to use these terms as chronostratigraphical units. We support this recommendation and the use of the terms PreBoreal, Boreal, etc. only in the cases the investigated sequences are supplemented with physical dates. In the new modified chart the chronozones and their time span in the radiocarbon years are the same as proposed in the scheme of the Nordic countries (Mangerud et al., 1974). Pre-Boreal, Boreal, Atlantic, and Sub-Boreal are divided into two (early and late), Sub-Atlantic into three subunits (early, middle, and late). In the Nordic chart the Atlantic, Sub-Boreal, and Sub-Atlantic follow a similar threefold division.

The second modification concerns the biostratigraphical part of the chart: instead of biozones the PAZs are presented and these, as timetransgressive units have not been strictly correlated with the chronozones. The borders between the PAZs are marked by fine lines indicating their time-transgressiveness. The main pollen producers describing roughly 
each of the zones are presented. The Pre-Boreal is characterized by the Betula-Pinus and Betula PAZs, the Boreal by the Pinus and Pinus Alnus PAZs. In the Atlantic the Ulmus-Corylus and Tilia-UlmusFraxinus PAZs have been proposed followed by the Quercus and Picea PAZs in the Sub-Boreal. In the Sub-Atlantic three PAZs are most common: Betula-Alnus in the early, Betula-Pinus-Picea in the middle, and Pinus-Betula in the late Sub-Atlantic.

\section{STRATIGRAPHY OF THE MARINE DEPOSITS}

Stratigraphically marine deposits are more difficult to divide than the continental ones because in many offshore and nearshore sequences gaps cover a longer time span than the preserved strata. For example, in the thoroughly investigated Moonsund (Väinameri) the thickness of the Holocene bottom sediments is everywhere less than $5 \mathrm{~m}$, in vast areas even less than $5 \mathrm{~cm}$ (Лутт, 1985). One of the challenges in deciphering the history of the Baltic Sea is the evaluation of the time span represented both by deposits and landforms, especially in the coastal areas. In earlier years, before the physical dating methods $\left({ }^{14} \mathrm{C}, \mathrm{ESR}\right)$ became available, the organic layers buried below the transgressive sediments were palynologically investigated. The countings of only tree taxa often led to wrong conclusions, when the deposits interpreted as having accumulated during the Pre-Boreal and Boreal were concerned. This, together with the "too young" radiocarbon dates were the main reasons why the Ancylus transgression maximum in Estonia was for a long time estimated to be several hundred years younger than in the Nordic countries.

As was mentioned above, the marine deposits are characterized by numerous unconformities and rapid changes in facies (Лутт, 1992). The evidence provided by sedimentary sequences in the Baltic Sea (Ignatius et al., 1981) has revealed four major stages in the Postglacial history of the Baltic: the Yoldia Sea, the Ancylus Lake, the Litorina Sea, and the Limnea Sea. Microfossil (mainly diatoms) and subfossil mollusc assemblages occurring in the sediments of these stages have complicated the interpretation problems. The units distinguished on the basis of littoral diatoms are variable, because changes in salinity are expressed differently in different areas. It is difficult to make any precise subdivision based on the floristic evidence coming mainly from the shallow-water deposits due to their discontinuous sequences.

On the Estonian shelf Lutt (Лутт, 1992) has differentiated seven more or less distinct lithological units which he associated with four main sedimentation stages of Late- and Postglacial time (Kiipli et al., 1993): (1) the formation of glacial and glaciofluvial deposits (Late-Glacial); (2) laminated clays (Late-Glacial); (3) sulphide-rich unclearly laminated clays and silts (mostly Ancylus); (4) laminated clays and silts with brackish-water fauna and flora (Litorina and Limnea). It is important to point out that lithostratigraphical units do not coincide with the chronostratigraphical ones.

As the stages in the Baltic Sea history have never been properly defined as stratigraphical units and they have no stratotypes, they are hardly comparable with each other. As far as the generally accepted standard division of the Baltic Sea sediments remains a task for the future, we dropped the traditional stage names in the descriptions of local and regional offshore sequences and started to use local unit names and numbers instead. A catalogue of all local unit and boundary stratotypes should be compiled, in which sites should be described, subdivided, and defined in a uniform way. 
Some kind of exception can be allowed for the supra-aquatic coastal area, emerged from the sea due to crustal uplift. Owing to the moderate land upheaval and the stability of shorelines during the transgressions in Estonia, the Ancylus and Litorina transgressional coastal formations are characterized by a greater thickness of deposits and greater variety and clarity of coastal relief forms than the regressional ones (Раукас, 1966). It serves as a good reason for distinguishing coastal zones of different ages and, accordingly, morpho- and lithostratigraphical units of different stages and phases of the Baltic Sea.

Transgressive shorelines of the Baltic Sea were for a long time identified as more or less synchronous formations. Depending upon the unequal land upheaval or sinking of the Earth's crust, transgressions culminated in different areas at different times (Кессел \& Раукас, 1984). We do not know the actual rates of tectonic and glacio-isostatic movements which undoubtedly differed in time and space (Miidel, 1994). This hampers seriously the correlation of the coastal formations all over the Baltic.

Based on the numerous studies on the Baltic Sea (Ignatius et al., 1981; Donner \& Raukas, 1988; Раукас \& Хюваринен, 1992; Eronen, 1992, for the eastern Baltic, and Svensson, 1989, for the central Baltic), the boundaries between the different Baltic Sea stages are given in the Table. The boundary between the Baltic Ice Lake and the Yoldia Sea is given at 10300 yr BP, between the Yoldia Sea and the Ancylus Lake 9300 yr BP, between the Ancylus Lake and the Litorina Sea $8000 \mathrm{yr}$ BP, between the Litorina Sea and the Limnea Sea 4000 yr BP.

\section{CONCLUSIONS}

The stratigraphical chart presented (Table) is only a small island of knowledge in the sea of ignorance. Therefore in the future similar compilations need more information about the history of the different palaeoecological type regions and stratotypes. The chronozone ages have been corrected following the Nordic chart, the subunits differ slightly from those presented in it, and PAZs are proposed. In the last years the semiquantitative estimation of palaeoclimatic parameters has become possible and the discovery of their influence on the ecosystems together with more precise dating methods would give a new approach to the stratigraphical studies.

As no generally accepted standard division of the Baltic Sea sediments can be expected in the nearest future, in local and regional sequences local unit names are preferred in descriptions. The comparison of the local divisions may then lead to the compilation of regional charts resulting in a more general stratigraphical chart for the Baltic proper.

All stratigraphical charts should be supported by appropriate unit and boundary stratotypes.

\section{ACKNOWLEDGEMENTS}

The authors are grateful to all Estonian Holocene stratigraphers of different generations, due to whose efforts the compilation of the present stratigraphical chart has turned possible. We would like to thank our colleagues, especially H. Nestor and A. Miidel, for helpful discussions, Mrs. H. Kukk for linguistic improvements. Financial support was obtained from the Estonian Science Foundation, grants Nos. 326 and 972, and ISF grants Nos. LG9000 and LK9100. 


\section{REFERENCES}

Aaloe, A., Mark, E., Männil, R., Müürisepp, K., and Orviku, K. 1960. Ulevaade Eesti aluspõhja ja pinnakatte stratigraafiast. Tallinn.

Aluve, K. 1978. Eesti NSV lääneosa ehitusmälestiste dendrokronoloogilisest dateerimisest. - Ehitus ja Arhitektuur, 2, 18-23.

Berglund, B. E. (ed.). 1979. Palaeohydrological Changes in the Temperate Zone in the Last 15000 Years. Subproject B. Lake and Mire Environments. - Dept. of Quat. Geol., Lund University.

Donner, J. J. 1971. Towards a stratigraphical division of the Finnish Quaternary. Comment. Phys.-Math., 41, 281-305.

Donner, J. and Raukas, A. (eds.). 1988. Problems of the Baltic Sea History. - Annales Acad. Sci. Fennicae, A, III, Geologica-Geographica, 148.

Eronen, M. 1992. Quaternary stratigraphy - a review. - Bull. Geol. Soc. Finland, 64, 2, 135-147.

Ignatius, H., Axberg, S., Niemisto, L. and Winterhalter, B. 1981. Quaternary Geology of the Baltic Sea History. - In: Voipio, A. (ed.). The Baltic Sea. Elsevier, Amsterdam, 54-104.

Kiipli, T., Liivrand, E., Lutt, J., Pirrus, R., Rennel, G. 1993. Pinnakate. - In: Lutt, J. and Raukas, A. (eds.). Eesti šelfi geoloogia. Tallinn, 76-103.

Kromer, B. and Becker, B. 1993. German oak and pine ${ }^{14} \mathrm{C}$ calibration, 7200-9439 BC. Radiocarbon, 35, 1, 125-135.

Laasimer, L. 1965. Eesti NSV taimkate. Tallinn.

Läänelaid, A. 1982. Põliste tammede iga. - Eesti Loodus, 1, 32-34.

Mangerud, J., Andersen, S. T., Berglund, B. E. and Donner, J. 1974. Quaternary stratigraphy of Norden, a proposal for terminology and classification. - Boreas, 3, $109-128$.

Miidel, A. 1994. Geological background of the present regional uplift anomaly in Estonia. - Proc. Estonian Acad. Sci. Geol., 43, 2, 69-83.

Mäemets, A. 1976. Lake types as basis for limnological division of the Estonian SSR. In: Raukas, A. and Tulp, L. (eds.). Estonia. Regional studies. Tallinn, 63-70.

Mäemets, A. 1977. Eesti NSV järved ja nende kaitse. Tallinn.

Orru, M., Širokova, M., Veldre, M. 1992. Eesti turbavarud. Tallinn.

Orviku, K. 1960. Eesti geoloogilisest arengust antropogeenis, II. - Eesti Loodus, 3, $139-150$.

Saarse, L. and Harrison, S. D. 1992. Holocene lake-level changes in the eastern Baltic region. - In: Merikalju, L. (ed.). Estonia. Man and Nature. Tallinn, 6-20.

Saarse, L. and Raukas, A. 1984. Background to a multidisciplinary investigation of mires, lakes and rivers. - In: Punning, J.-M. (ed.). Estonia. Nature, Man, Economy. Tallinn, 78-87.

Saarse, L., Pirrus, R., Sarv, A., Mäemets, H., Rõuk, A.-M., and Ilves, E. (in press). Estonia. Contribution to the IGCP Project No. 158. Elsevier.

Svensson, N. O. 1989. Late Weichselian and Early Holocene shore displacement in the Central Baltic, based on stratigraphical and morphological records from eastern Småland and Gotland, Sweden. - LUNDQUA Thesis, Lund, 25, 1-195.

Tammekann, A. 1933. Eesti maastikutüübid. - Loodusuurijate Seltsi Aruanded, 39, 1/2. Tartu, 3-21.

Thomson, P. 1925. Eesti soode ja järvelademete stratigraafia. - Sookultuur, 3.

Thomson, P. 1930. Soode arenemine ja kliima muutused. - Loodusvaatleja, 6, 163-169.

Thomson, P. 1933. Moorstratigraphische Notizen aus Estland. - Beitr. zur Kunde Estlands, XVIII, 3. Tallinn, 1-3.

Thomson, P. 1939. Olevaade Eesti soodest. - Eesti Loodus, 2/3, 90-98.

Varep, E. 1964. The landscape regions of Estonia. - Publications on geography. Trans. of the Tartu State University, 156, 3-28.

Ильвес Э., Лийва А., Пуннинг Я.-М. 1974. Радиоуглеродный метод и его применение в четвертичной геологии и археологии Әстонии. АН ЭССР, Таллинн.

Каяк К., Кессел Х., Лийвранд Э., Пиррус Р., Раукас А., Сарв А. 1976. Местная 
рабочая стратиграфическая схема четвертичных отложений Әстонии. - In: Стратиграфия четвертичных отложений Прибалтики. Пяргале, Вильнюс, $4-52$.

Кессел Х. 1960. О геологии голоценовых береговых образований Балтийского моря на территории Эстонской ССР. - Тр. Ин-та геол. АН ЭССР, V. Таллинн, 279303.

Кессел Х. 1961. Древние береговые образования бассейна Балтийского моря в Әстонской ССР. - Тр. Ин-та геол. АН ЭССР, VIII. Таллинн, 113-131.

Кессел Х. 1966. Стратиграфическая схема Балтийского бассейна на территории Эстонии. - In: Орлова Г., Орвику К. (eds.). Развитие морских берегов в условиях колебательных движений земной коры. Валгус, Таллинн, 36-43.

Кессел Х., Раукас А. 1981. Геологическое развитие Балтийского моря в Эстонии и корреляция опорных уровней. - In: Раукас A. (ed.). Корреляция под- и надводных отложений и форм рельефа южной и средней Балтики. Ин-т геол. АН ЭССР, Таллинн, 5-11.

Кессел Х., Раукас А. 1984. О геологической корреляции древнебереговых образований Балтийского моря в Эстонии и Швеции. - Изв. АН ЭССР. Геол., 33, $3 / 4,146-157$.

Лутт Я. 1985. Донные осадки Вяйнамери. Валгус, Таллинн.

Лутт Я. 1992. Донные осадки. - In: Раукас А., Хюваринен Х. (eds.). Геология Финского залива. АН Эстонии, Таллинн, 158-218.

Орвику К. 1956. Стратиграфическая схема антропогеновых четвертичных отложений на территории Эстонской ССР. - Тр. Ин-та геол. АН ЭССР, І. Таллинн, $105-112$.

Орвику Л. 1960. Современное состояние палинологических исследований в Әстонской ССР. - Тр. Ин-та геол. АН ЭССР, v. Таллинн, 317-337.

Пуннинг Я.-М., Илометс М., Кофф Т., Раямяэ Р. 1985. Комплексные стратиграфопалеогеографические исследования озерно-болотных отложений во впадине Вялламяги, ЮВ Эстония. АН ЭССР, Таллинн.

Раукас А. 1966. Образование трансгрессивных прибрежных толщ Литоринового моря и Анцилового озера в Эстонии. - In: Орлова Г., Орвику К. (eds.). Развитие морских берегов в условиях колебательных движений земной коры. Валгус, Таллинн, 30-34.

Раукас А. 1978. Плейстоценовые отложения Эстонской ССР. Валгус. Таллинн.

Раукас А., Хюваринен Х. (eds.). 1992. Геология Финского залива. АН Эстонии, Таллинн.

Сарв А., Ильвес Э. 1975. О возрасте голоценовых отложений приустья реки Эмайыги (по материалам изучения разреза Савику). - Изв. АН ЭССР. Хим. Геол., 24, 1, 64-69.

\title{
EESTI UUS, TÄIUSTATUD HOLOTSEENI SETETE STRATIGRAAFILINE SKEEM
}

\author{
Anto RAUKAS, Leili SAARSE, Siim VESKI
}

Ulevaates on esitatud uus, 1993. aastal kinnitatud Eesti Holotseeni setete stratigraafiline skeem (tab.), mis on korreleeritud Põhjamaade ja Baltimaade skeemiga. 
НОВАЯ УСОВЕРШЕНСТВОВАННАЯ СТРАТИГРАФИЧЕСКАЯ СХЕМА ГОЛОЦЕНОВЫХ ОТЛОЖЕНИИ ЭСТОНИИ

Анто РАУКАС, Лейли СААРСЕ, Сийм ВЕСКИ

Представлена принятая в 1993 г. новая стратиграфическая схема голоценовых отложений Эстонии, которая имеет параллельные подразделения для континентальных и морских фаций. Возрастные границы хронозон скоррелированы с соответствующими границами в Скандинавских и Прибалтийских странах, 